\title{
About the use of Longitudinal data Analysis in Forage Legumes Breeding: A Review
}

Daniela Popim Miqueloni

Federal University of Acre, BR 364 km 04, Rio Branco, AC, Brazil.

Email: danimique@yahoo.com.br

\begin{abstract}
Forage breeding is more complex than that practiced in other plant species. In addition to assessing the effect of superior genotypes through animal performance, there is a need to evaluate genetic materials over time, which requires the use of appropriate tools and statistical methods so that all effects of the environment are captured and analyzed due to the perennial character of these species. Another significant factor with regard to forage legumes is the analysis in pure or mixed stands, which may facilitate the conduction of trials in the first case and improve the adaptive ability evaluation of species with associated plant and the environment effects in the second case. In this context, the interaction of the genotype with the environment, which differs for the temperate and tropical legume species, is discussed from the point of view of the longitudinal data analysis by application of the mixed model methodology, also considering the employment of mixed pastures in the tropical region of the globe.
\end{abstract}

Keywords-Genotype $x$ environment interaction, measures over time, mixed pasture, perennial species, tropical and temperate legumes.

\section{INTRODUCTION}

The Fabaceae family, or commonly known as legume, comprises from 650 to 750 plant genera, with 18,000 to 19,000 species among grain, pasture, and agroforestry species, and it is second in importance to human activities, behind only grasses species (Graham and Vance, 2003). In addition to being source of protein, lipids and carbohydrates in food and feed, legumes perform a crucial role in different ecosystems by biological nitrogen fixation, ensuring the maintenance of biological activity and the cycling of nutrients, thus improving soil and pasture quality (Miranda et al., 2010; Boelt et al., 2015).

Perennial legumes are considered an essential component for the maintenance of sustainable agroforestry and production systems (Annicchiarico et al., 2015). By the other hand, especially in Brazil, the lack of diversity due to the massive presence of few forage varieties, mainly apomictic grasses, makes the pastures dangerously susceptible to pests and diseases, which has the potential to devastate massive areas (Araújo et al., 2008). In this sense, less than $1 \%$ of total pastures area in Brazil is composed of forage legumes, which fails to generate significant benefits such as the contribution of nitrogen in soil and source of high quality protein in animal nutrition (Simeão et al., 2015). Another significant benefit is the regeneration of degraded pastures; prevent the increase of agricultural frontier, mainly in the Amazon region (Assis et al., 2008). Otherwise, in temperate regions, legumes are widely used and studied, mainly for their economic and environmental benefits (Valle et al., 2009; Annicchiarico et al., 2015).

In the current context, where there is a human population rising, a greater demand for animal and non-animal products and a reduction of pasture and cropping areas, the genetic improvement of forages is the most sustainable option for increasing production due to its technical and economic implications (Araújo et al., 2008; Simeão et al., 2015). However, in contrast to conventional breeding programs, agronomic performance is only one among the several factors analyzed in forage breeding where the focus stays on animal performance. Thus, knowledge of the complex environment $\mathrm{x}$ plant interaction becomes essential for success in the selection of interest genetic materials.

\section{TROPICAL FORAGE SPECIES BREEDING}

The genetic improvement of forages in Brazil is a recent activity, intensified only in the last decades, but with the development of highly adapted and productive cultivars (Jank et al., 2011). In general, forage species breeding programs aim to increase yields of dry matter and seeds, resistance to biotic and abiotic stresses, persistence and nutritional quality (Hayes et al., 2013; Resende et al., 2008). 
The structure of these breeding programs is basically composed of three phases, which can vary from six to eleven years (Assis, 2009). In the initial phase, the goal is to obtain new genotypes; second phase focuses in selection; and the final phase aims the recommendation for release of superior genetic materials. All over the program, the number of genotypes under evaluation decreases, starting from a considerable quantity of highly divergent genetic materials to a reduced number of higher yields for the characteristics of interest (Jank et al., 2014). In general, the improvement of the initial genetic materials, mainly of grasses, is practiced by the recurrent selection methods based on the phenoty pe (Resende et al., 2014). Experimental evaluations and selection practices tend to vary according to the type of progeny and estimation methods, which should consider, among other things, the species and its reproductive system, available germplasm, growing environment and type of cultivar to be released (Annicchiarico et al., 2015; Hayes et al., 2013).

In the 1980s and 1990s, the introduction of forage cultivars in Brazil occurred through the agronomic evaluation and selection of superior clonal accesses validated in grazing trials (Simeão et al., 2015). The breeding methods for tropical legumes were those used in annual autogamous and alogamus species, although most tropical legumes were perennial with mixed breeding systems. In fact, this demonstrated some effectiveness, but failed to explore strategies and characteristics important to perennial species, such as persistence (Resende et al., 2008). In addition, significant failures were related to agronomic characteristics, such as lack of disease resistance and low seed production; and in the market chain, as a lack of seed harvest systems and distribution of these seeds, resulted in a low rate of adoption of forage legumes by Brazilians producers (Resende et al., 2008; Shelton et al., 2005).

On the other hand, there are cases of success, mainly in the western region of the Brazilian Amazon, that use mixed pasture with forage peanut (Arachis pintoi) and tropical kudzu (Pueraria phaseoloides), and in the central region of the country, employng the common stylo cultivar Campo Grande (Stylosanthes capitata and S. macrocephala) (Shelton et al., 2015). In Brazil's South region, because of the edaphoclimatic characteristics, there is a small but growing use of temperate forages such as alfalfa and clover (red and white) in the animal production system (Montardo et al., 2003; Peres Netto et al., 2011; Schneider et al., 2011).

\subsection{Use and importance of forage legumes}

Forage legumes are suitable for multiple purposes, such as increasing the sustainability of production systems which is the most required due to their relative tolerance to abiotic stresses, persistence, vigor and longevity in several systems, and the easy establishment (Annicchiarico et al., 2015; Shelton et al., 2005). They also provide high-quality feed for animals, nectar, seeds, green manure and soil cover, making them an critical component of the production of wool, milk and meat under pasture in the world and bringing increases up to $50 \%$ of animal productivity (Barcellos et al., 2008; Boelt et al., 2015).

Although many perennial leguminous species offer potential for use as forage, few are in fact employed (Valle et al., 2009). However, only in the last few years, with the increasing concern about environment and sustainability of production systems, forage legumes have been prominent in animal production, mainly in temperate regions of the globe (Andrade et al., 2015; Batello et al., 2008). Alfalfa (Medicago sativa and M. falcata) is considered the most widely used legume species, distributed in about 30 million ha in the Northern Hemisphere and South America and expanding its area in recent years to Australia and China (Annicchiarico et al., 2015). White clover (Trifolium repens) is preferred in some regions of temperate climate and more intensive grazing, mainly in Western Europe, United States and South America, while red clover ( $T$. pratense) is the predominant species used in Northern Europe. Besides, white clover is widely managed in mixed pastures in several countries, while alfalfa and red clover are managed under mowing regime and rotation grazing (Annicchiarico et al., 2015; Batello et al., 2008).

In Brazil, tropical forage legumes are predominantly used in consortium with grasses of African origin (Panicum, Brachiaria and Pennisetum) (Valle et al., 2009). Initially, most of the cultivars managed were developed and commercialized by Australia and, due to their wide distribution through natural pastures and cultivated areas, mostly from South America, they were poorly studied, resulting in a large amount of unexplored genetic material (Araújo et al., 2008; Valle et al., 2009).

The forage peanut (Arachis pintoi and A. repens) and the common stylo (Stylosanthes guianensis, S. scabra, S. hamata, S. humilis, S. capitata, S. macrocephala) are the herbaceous species mostly used in Brazil, and less frequently used species of the genus Desmodium, Centrosema, Neonotonia and Pueraria, this is more pronounced in the Western Amazon; besides shrubs species like Cajanus, Leucaena and Cratylia (Barcellos et al., 2008; Valle et al., 2009). Although the main legume 
forage species are native to Brazil, there is a reduced rate of adoption by the producers, resulting in insignificant area of cultivation in relation to grasses, mainly of the genus Brachiaria. On the other hand, the economic importance of these legume species has demonstrated considerable economic value in the animal production of Asian and African countries (Valle et al., 2009). In Brazil, the mixed pasture of grasses and common stylo cultivar Campo Grande, a seeds physical mixture of $80 \%$ of $S$. capitata and $20 \%$ of $S$. macrocephala, extends for about 1.7 million ha; thus far 140,000 ha of pasture are mixed with forage peanuts and 148,000 ha with tropical kuzdu, only in the State of Acre, which comprises the largest area of these mixed pastures in the country (Embrapa, 2013; Valle et al., 2009; Shelton et al., 2005).

\subsection{Forage Legume breeding}

The employment of temperate species of forage legume is much more prior than the use of tropical legumes. Originating in the Mediterranean region, some of these species went through domestication even before the Christian era, with records of its use in Europe from the time of Roman domination to the renaissance and with large-scale systematic selection for over a century ago (Annicchiarico et al., 2015; Batello et al., 2008). On the other hand, the interest in tropical forage legumes raised in the 1930s in Australia, where increases were observed in the rates of animal production in native pastures due to introduction of common stylo species, which was studied and later transformed into technology and exported to the other tropical regions (Rao et al., 2015). From the 1960s, there was more active interest in the introduction of legumes adapted to animal production systems in tropical regions, which led to the creation of collections of germplasm collected mainly in Latin America and the Caribbean (Resende et al., 2008).

Temperate forage legumes are predominantly alogamus and suffer severe inbreeding depression (Annicchiarico $e t$ al., 2015). The majority of the tropical ones have mixed system of reproduction, tending to autogamy (Jank et al., 2011; Simeão et al., 2015). These conditions imply in different population structures and, consequently, in variation between and within families and populations, these conditions also changing the selection strategies, that must be chosen according to the predominant mechanism of reproduction of each species (Annicchiarico, 2002; Garcia et al., 2013; Hayes et al., 2013; Pereira et al., 2003).

Initially, selection for most temperate and tropical legumes was carried out by massal selection, from a broad genetic base, focused primarily on disease resistance and grazing tolerance, and less emphasis on progeny tests and diallel crosses (Annicchiarico et al., 2015; Resende et al., 2008). Massal selection has the advantage of facilitating the development of cultivars resistant to multiple pests and diseases and also minimizes inbreeding depression that may occur during recurrent selection cycles, but limits the concentration of favorable alleles during the exclusion of undesirable alleles and restricts quantitative inheritance gains (Annicchiarico et al., 2015; Simeão et al., 2015).

Currently, natural variability has already been widely explored for temperate species, while breeding by selection of ecotypes that occur directly in nature is still used for tropical species, since the genetic variability of the germplasm collections is little studied (Araújo et al., 2008; Simeão et al., 2017). This unequal development is also observed in the application of molecular techniques, routinely used in temperate species and recently applied in tropical ones, with lacking of fundamental studies such as establishment of DNA extraction protocols and choice of molecular markers (Araújo et al., 2008; Valle et al., 2009).

\subsubsection{Criteria and methods of selection}

A selection cycle in temperate and tropical forage breeding typically requires 3 to 5 years, with evaluation of individuals or families over several harvests (or crops) to measure the selection criteria (Simeão et al., 2015). These criteria are usually based on yield (dry matter and seeds) and resistance to pests and diseases; persistence capacity (survival, precocity, establishment and competition); and quality (nutrient contents, digestibility and palatability), which are directly related to each other and to the objectives of breeding (Resende et al., 2008). During this period, there may be a need to modify the breeding method, part of the strategies to better exploit the intrinsic characteristics of the forage species, such as vegetative propagation, perennial cycle, gene exchange with other species, in order to increase the efficiency of the program (Annicchiarico, 2002; Pereira et al., 2003).

For temperate legumes, Annicchiarico et al. (2015) claim that greater gains are obtained through the employment of breeding schemes that use hybrid selection or pure lines, aimed at the development of synthetic varieties, with commercial seed production by several generations of open-pollinated progenies after the parental selection. Parents can be obtained by evaluation of clones or progenies of full-siblings or half-siblings, constitute a step of considerable importance to determine the genetic potential, genetic basis, and the degree of endogamy 
reached by the following generations (Annicchiarico et al., 2015; Pereira et al., 2001).

The constitution of synthetic varieties, an inter-population selection method, provides more possibilities of genetic base amplification and favorable alleles maintenance and it is originated from the crossing of lineages or clones of successive generations planted in bulk, that is, with the seeds harvested together and sampled for planting (Pereira et al., 2001). For high-heritability characters in alfalfa, Pereira et al. (2001) point resistance gains by intrapopulational methods, in individuals (such as maternal selection, clonal lines and progeny tests) and within populations.

Most of the characteristics of interest in temperate legumes, as well as in tropical ones, retains quantitative heritage. In this case, the additive genetic variation assumes significant role in the gains by recurrent phenotypic selection, although the non-additive genetic variation (or dominance genetic variation, ignoring the epistasis) is considerable for dry matter yield in alfalfa (Annicchiarico et al., 2015; Hayes et al., 2013). In this aspect, the presence of non-additive variance in high magnitude, as observed for dry matter production characteristics in S. capitata open-pollinated progenies, can be translated into high heterosis, and should be very carefully investigated to increase the gains (Resende et al., 2008). In addition, adaptation ability is a critical factor for many productive characteristics of temperate legumes and an approach to improve the performance of already used fodder is by hybridizing elite populations with locally adapted and resistant ecotypes (Annicchiarico et al., 2011; Oliveira et al., 2013).

Among the selection criteria for temperate legumes, the target characters are those related to production, dry matter and seeds; resistance, mainly to drought and soil acidity; and compatibility with grasses (Annicchiarico et al., 2015). In this aspect, correlations with morphophysiological characteristics can be explored in the identification and indirect selection of superior genetic material, such as leaf senescence related to drought tolerance or flowering for alfalfa seed production and aerial morphological characteristics related to competitive ability in white clover, without the need for higher cost techniques, such as molecular markers (Annicchiarico, 2003; Annicchiarico et al., 2011; 2015).

Currently, for the main tropical species, the obtaining of divergent genetic materials and the selection of superior individuals practice the techniques of hybridization and generations advance for forage peanuts, and the recurrent selection among and within families for stylo (Assis; Valentim, 2009a; Andrade et al., 2015). In Brazil, promising hybrid lines are also being evaluated (Assis et $a l ., 2018)$ and in Australia, recurrent selection was used with genetic markers to identify recombinant natural crossbreeding plants in stylo, but the genealogical method was widely used in several countries for forage and seed yield in species of the genus (Pereira et al., 2001). This method is equally interesting for forage peanut that originated from a base population representative of genetic variability, obtained by inter or intraspecific hybridization, as a result of natural or artificial recombination (Assis; Valentim, 2009b).

Resistance to anthracnose is one of the selection criteria demands for stylo cultivars, and for forage peanut is sought also seed production, rapid establishment and production of dry matter and tolerance to drought (Andrade et al., 2015; Assis; Valentim, 2009a; Resende et al., 2008).

\subsubsection{Selection in pure or mixed stands}

The benefits of grass and legume pasture mixed have been widely sought in world livestock production (Annicchiarico et al., 2015; Barcellos et al., 2008). The white clover and perennial ryegrass (Lolium perenne) mixed pasture, because of its characteristics suitable to form productive and resilient systems, is an example of success in many temperate regions, becoming the most important mixed pasture in the world (Andrade, 2013). However, the mixed pasture technology did not achieve the same success in the tropics showed few adoption cases, mainly in Brazil (Shelton et al., 2005; Simeão et al, 2015).

Among the causes for this lack of interest in mixed pasture cultivation remain the failures of forage breeding programs, which in the traditional selection process do not consider the key characteristics for good performance of the botanical families involved, such as plant architecture and persistence (Andrade, 2013; Simeão et al., 2015). In addition, the lack of seed production for mixed pasture implementation increases the costs of adoption because making the propagation process predominantly by seedlings, even when the legume has the desirable characteristics, as in the case of forage peanuts (Andrade et al., 2015; Resende et al., 2008).

According to Andrade (2013), there have never been programs to improve tropical grasses aiming to obtaining germplasm compatible with legumes. Thus, the selection of the superior legume genetic materials is carried out on pure stands and, later, its ability to association with commercial grasses is tested, often producing unsatisfactory results. In this sense, the efficiency of selection in pure stands can be questioned, since the 
species will be utilized together and the effect of a possible interaction between cultivars, as well as their behavior against grazing stress, are neglected (Andrade, 2013; Andrade et al., 2015). In addition, many aspects of the competitive ability of the legume, whether broad or relative response to the type of associated grass, have not yet been fully elucidated for tropical legumes, as observed for white clover varieties, for example, with a consistent response to competition ability with several grasses (Andrade et al., 2015; Annicchiarico, 2003).

The complexity of forage breeding to use in mixed pastures is greater than the breeding for use in pure stands, which generally does not provide information about the behavior of forage in a mixed pasture (Andrade, 2013). Moreover, the competitive ability of the species in pure and mixed stands can be variable, since the yield in mixed pastures is attributed to the adaptive capacity and the intrinsic characteristics of each species, such as physiological needs of legumes plants belonging to $\mathrm{C} 3$ photosynthetic group and grasses, belonging to $\mathrm{C} 4$ group, which would be evaluated more efficiently together. (Annicchiarico, 2003; Assis et al., 2008; Volaire et al., 2013). On the other hand, satisfactorily established correlations among interest characters associated, such as length and density of stolons and lengthening of the petiole associated with the ability to competition in white clover, can be used as initial selection criteria in monoculture (Annicchiarico, 2003). In addition, the evaluation performed in pure stands can be less expensive than in mixed stand, since it does not require the botanical components separation (Andrade et al., 2015).

In this sense, the initial selection can be directed to the search of characters aimed at increasing the persistence and compatibility between species, which today are more known and discussed characteristics, however that needs the analysis of a particular set of species or cultivars, according to their intrinsic characteristics (Andrade, 2013; Andrade et al., 2015).

According to Andrade (2013), the persistence of legumes in pasture depends on two mechanisms: those that guarantee the perennial or maintenance of the population, as plant longevity and production of seeds or stolons and rhizomes; and those that regulate their adaptation to grazing, such as growth points or greater regrowth capacity. Compatibility is defined by several factors, such as palatability; mechanisms for population maintenance; tolerance to defoliation and trampling; morphological plasticity; response to nutritional limitations; tolerance to drought or water excess; competition for light and space; root system pattern; and the habit of growth. This last one, according to the author, is the most important and decisive factor, in which prostrate leguminous species have advantages over upright or volatile ones due to the initial defoliation of grasses and consequent increase of light entrance, besides of keeping restricted the animal access to its regrowth points, a more photosynthetically active part of the plant, allowing its rapid recomposition.

\section{LONGITUDINAL DATA ANALYS IS METHODS}

According to Resende et al. (2008), because of perennial or semi-perennial characteristics, the forage species present several aspects that differentiate their genetic improvement from the genetic improvement practiced in the annual species, such as generation overlap, sexual reproduction with variation in self-fertilization rates, asexual reproduction and expression of characteristics over several years, but with annual behavior regarding the reproductive cycle. These factors lead to the utilization of selected individuals for several years, which demands greater accuracy and precision in selection methods, use of repeated evaluations over the years, importance of individual over the average of groups for selection purpose, and reduction of survival rate, which causes unbalance of experiments (Resende, 2002). In addition, the estimation methods in perennial plants breeding should consider a coefficient of genetic determination, as well as possible heterogeneity and non-independence of residual variances among the cultivars or genotypes, because of their perennial character, as a result of repeated measures carried out throughout the evaluations (Resende and Duarte, 2007).

Repeated measures are evaluations performed with interest factor several times, and when these measures are generated over time, they are called longitudinal data. In these cases, the researcher's interest lies in the whole data set and not only in evaluations individually, since they do not contemplate the effects of the treatments over time and their interactions among measurements, besides the effects within the evaluated plot itself. (De Faveri et al., 2015; Freitas et al., 2008; Littel et al., 2000; Resende et al., 2008). These measures, because they originate from the same sample, are not independent, showing possible autocorrelation patterns, that is, serial correlations; and taken non-randomly at intervals of time, which promotes the need for specific analysis methods (Onofri et al., 2010; Piepho and Eckl, 2014).

In the context of genetic improvement, data analyzes were initially based on the analys is of variance (ANOVA), a method developed by Fisher at beginning of the 20th century, which divides the total variation of data into sources due to genotype, environments (in cases where 
there is more than one evaluation site), harvests, also called crops or cuts, and all interactions between these sources, as well, the errors within the test (Smith et al., 2005). Because of the computational facility, the momentum methods, where the average squares of each component or source of variation are equated to their respective mathematical expectations to estimate the components of variance, are still widely used (Coelho and Barbin, 2006; Freitas et al., 2008). However, this approach leads to assumptions that should not be ignored, under threat of biased estimates of effects: normality, homogeneity of variances, and independence of sample errors, which are generally not observed in field trials, especially for perennial species (Onofri et al., 2010; Resende, 2002). In the absence of compliance with these requirements, artifacts such as adjustments in degrees of freedom and data transformation can be employed, but are not always effective solutions (Freitas et al., 2008; 2011). Onofri et al. (2010) state that, even if used properly and solving most of statistical problems in a simple way in agriculture, the application of ANOVA, although not technically incorrect, may be inefficient in cases of unbalanced trials in various environments or longitudinal data. For the longitudinal data case, a possibility of analysis would be by the average of subsamples or individually for each measurement, but feasible only in balanced cases and lead to loss of variation information; or analysis of the entire data set with distinction of two error levels for the experimental units allocated to the plots, which generally corres pond to the genotypes, and to the observation units allocated to the subplots, generally for measures over time (Freitas et al., 2011; Onofri et al. 2010). In the case of measures over time, the use of the scheme in split-plot must necessarily satisfy the condition of sphericity, that is, the variances of the difference between pairs of errors are all equal (Freitas et al., 2008; Huynh and Feldt, 1970).

On the other hand, an efficient solution to analyze these data is the methodology based on mixed models, which considers fixed components in the model, except the general average, and random components, except the error, and uses procedures considered optimal to estimate the genetic parameters and predict the genotypic values, with adjustment of the variance and covariance structure of errors (Littell et al., 2000; 2006; Piepho Möhring, 2006; Resende, 2002).

Although the definition of fixed and random components of the model is controversial and Resende and Duarte (2007) affirm that the relevance of the method lies in the choice of the most accurate estimators and predictors, since the number of observations influences the definitions of fixed and random components, in a simplified way in genetic improvement, the fixed components contemplate the measures over time and environmental effects, with the measurements allocated in what would be the subplots of the ANOVA. The random components are the genotype effects and their interactions, allocated in the equivalent of the plots, and go through adjustments of functions, obtaining regression parameters, as well residue and component of variance for each parameter (Onofri et al., 2010). In this way, the method offers two advantages: the experimental design is reflected by the analysis, with all levels of errors; and the adjustment of several structures of variances and covariance for the serial patterns, generally with decreasing correlations due to the increase of distances among them, improving the estimations (Littell et al., 2000; Piepho et al., 2008).

In the data analysis by mixed models, in spite of e several methods available for estimation of the components of variance, the most used approach is the frequentist based on the likelihood methods, mainly by the Restricted Maximum Likelihood (REML), which is based on maximization of the likelihood function independent of fixed effects and considering its degrees of freedom (Patterson; Thompson, 1971; Resende, 2002). The prediction of value method is based on the Best Linear Unbiased Prediction (BLUP) (Henderson, 1973) and includes: best prediction (BP), available when all parameters of joint data distribution and genetic values (unobservable) are known; best linear prediction (BLP), when the first and second moments (mean and variance) of data are assumed to be know; and better linear unbiased prediction (BLUP), where only the second moments are assumed to be know (Resende, 2002). At this point lies the importance of using reliable estimators, since such components are not in fact known and should be appropriately estimated (Resende and Duarte, 2007).

According to Resende et al. (2008), the evaluation of genetic materials has the objectives of inferring about their genotypic values and ordering the materials based on these values. Genotypic values are the true values sought for the genotypes, that is, the actual values of cultivation and use, without the influence of the effects of blocks, plots and environmental effects that, even when evaluated in the same place, are intrinsic to the experiment and integrate the variable phenotypic value of genetic material. (Resende and Duarte, 2007). Thus, the actual interest in the genotype evaluation trials is to estimate their genetic values, as a result of the mixed model approach, and not only the phenotypic values provided by ANOVA. 
Under the mixed model approach (REML/BLUP), perennial species with repeated measurements can be evaluated considering these measures as distinct characters, in other words, individual or average of all evaluations; or as a single character, with each approach offering diverse levels of genotype information. Considering as distinct characters, it is possible to evaluate the change in character over time (age), the utilization system of the crop and the weighting of genetic values predicted by harvest, such as the evaluation in different seasons of the year, for example, drought and water; in addition the search for initial selection based only on the first harvest and the verification of homogeneity of genetic and environmental variances in the different harvests, with their respective heritabilities (Resende et al., 2008). Likewise, it is possible to determine confidence intervals of predicted genotypic values, which allow inference on multiple comparisons among genotypes; as well, the use of harvest average, but only for balanced cases and with less informative result, without repeatability and interaction genotype $\mathrm{x}$ harvest (Resende, 2002).

In the case of a single character, the model of repeatability can be adopted, which contemplates the genotype, block, harvest and their interactions effects, considering equally the permanent effect of plots (genotype $\mathrm{x}$ block interaction), essential to eliminate the residual correlation effects among repeated measures, since there is no randomization of plots among harvests (Resende et al., 2008). Even with imbalance, this model provides the simultaneous estimation of heritability and individual repeatability, average heritability of genotypes, which provides the accuracy of selection, and genetic correlations through harvests and permanent environment (Resende, 2002). All these parameters are extremely informative and essential to define the most effective strategies for selection and cannot be obtained by ANOVA, another fact that restricts the use of ANOVA for genetic improvement of forage species (Piepho and Möhring, 2006; Resende et al., 2008).

Other methods of longitudinal data analys is are still being used in to improve perennial plants, like random regression, which include several approaches such as covariables, spatial and multivariate analysis (Resende $e t$ al., 2006a; Wang et al., 2009; Zamudio et al., 2008).

\subsection{Selection criteria dependent on longitudinal data}

The identification and selection of the superior genetic material and the increase of the gains rates are directly dependent of the statistical methods used for modeling the genetic effect and for predicting the true potential of each genotype, and these methods, in turn, are linked to the objectives of the trial and the plant characters involved (De Faveri et al., 2015).

Productivity and resistance are some of the most important selection criteria in perennials species. However, the permanent character of these species brings the need for analysis over time, since environmental influence has great magnitude in the characters of production and brings the aspect of seasonality to pests and diseases incidence, e directly related to the plant resistance capacity (Cilas et al., 2011; Pereira et al., 2001; Rubiales et al., 2015). Measures obtained repeatedly over time allow the determination of the characters repeatability, a significant parameter to predict genotypic and phenotypic values, making an inference about the phenotypic correlation among the repeated measures in the same individual (Resende, 2002). In addition, the joint analysis of these various measures allows selecting materials by genetic values based on their stability and adaptability along the harvests (Resende, 2007).

According to Pereira et al. (2001), the ability to adjust to environment and the constant behavior in diverse conditions are characteristics of adaptation and stability of genetic material and are related to its genetic constitution. These characteristics are critical because they are linked to the response to environmental improvement conditions and to the predictability of genotypes, which determine the commercial success of a cultivar (Cilas et al., 2011; Resende et al., 2008).

In perennial forage species, persistence is another important selection criteria evaluated through precocity and survival capacity, establishment and competition, and, jointly with productivity, is linked to the information of production superiority measured in several harvests (Resende et al., 2008). Resende et al. (2008) comment that these characters are directly related to each other, since persistence is linked to survival capacity, which depends on longevity, competition capacity and natural resemblance, and this resemblance, in turn, is one of the factors of considerable importance in strategies for management of mixed pastures. In addition, survival capacity, a character often ignored in breeding programs, assumes crucial importance, as reported by Resende et al. (2006b) for stylo, influencing the low rate of adoption of the legume in Brazil (Simeão et al., 2015).

\subsection{Longitudinal data on forage breeding}

The employment of longitudinal data on forage breeding is widely diffused for both temperate and tropical species. This is an important way to obtain information from experimental trials that try to detect trends of genotypes 
over time, since simpler methods, even in well-designed and conducted trials, can compromise the detection and analysis of relevant effects (Annicchiarico, 2002; De Faveri et al., 2015; Locascio and Atri, 2011).

The use and analysis of longitudinal data allowed considerable advances in the improvement of temperate forages, allowing the exploration of the adaptive and morphological characteristics of many species, for example obtaining alfalfa genotypes tolerant to salinity and drought and resistant to intensive grazing for the Mediterranean region, as well genotypes with variability for potential use in tropical regions, such as in Southeast Brazil (Annicchiarico et al., 2011; Assis et al, 2010). White clover genotypes where also observed showing adaptive characteristics for warmer conditions of Brazilian Southern region and distinction and classification of genotypes for several applications in Europe, such as landscaping, besides the traditional grazing and hay (Oliveira et al., 2013; Schneider et al., 2011).

The competitive capacity of white clover for mixture with grasses was also evaluated, suggesting being a consistent character in the species (Annicchiarico and Proietti, 2010). In addition, the importance of evaluation in mixed stands, as well as the use of selection indexes that incorporate productive and morphological characteristics, has been proven (Annicchiarico, 2003).

The application of longitudinal data has contributed to the methodology and strategies for conducting programs of forages genetic improvement. An example is the understanding that genotype selection in spaced plots for further performance trials in densified plots is less efficient, especially for characters subject to genotype $\mathrm{x}$ harvest interaction, such as yield of dry matter and seeds, compared with the selection made directly in the denser plots, which better reproduce the field environment for white clover (Annicchiarico and Piano, 2000). In addition, the incorporation and analysis of the serial and spatial correlation effects among harvests and among trials, as well as the distinction of the evaluation year effect, associated with the external environmental variation and the harvest effect, which represents the formation processes of culture internal income, bring more accurate estimative of parameters (De Faveri et al., 2015; Piepho and Eckl, 2014).

For tropical forages, the longitudinal data analysis has allowed the estimation of genetic parameters and prediction of genotypic values of several genotypes of grasses, which enables the identification of superior genetic materials for crossing and selection, identification of genotypes adapted to regional conditions and determination of selection indexes for classification of genetic materials with better forage production throughout the year (Figueiredo et al., 2012; Resende et al., 2004; Silva et al., 2010; Simeão et al., 2016). In addition, this analysis allowed to establish the ideal number of measures with high reliability for the characterization of dry matter production in Brachiaria and Panicum species, thus optimizing the evaluation time (Basso et al., 2009; Lédo et al., 2008; Martuscello et al., 2015; Souza Sobrinho et al., 2010).

In legumes species, it was possible to detect genetic variability in $S$. capitata genotypes related to anthracnose resistance, a disease that has limited its commercial use, and higher persistence capacity of stylo genotypes in the pasture (Assis et al., 2018; Falco et al., 2016). In addition, there was the identification of forage peanut ecotypes for use in mixed pastures in Brazilian Cerrado and genotypes with shorter establishment time and lower harvest frequencies (Assis et al., 2008; Ferreira et al., 2013; Simeão et al., 2017; Valentim et al., 2003). In evaluations of mixed pastures, forage peanut systems showed similar results to systems with white and red clover related to forage production, nutritive value and control of spontaneous species, demonstrating also potential for higher animal load on pasture in summer season in region South of Brazil (Diehl et al., 2013; Olivo et al., 2010; 2012).

\subsection{Genotype $x$ harvest interaction}

In forage breeding, agronomic researches are essential to obtain information about the genotypes behavior and responses to environment, use and management factors. Harvest trials are important for determining yield, regrowth capacity and management systems, as well as adaptability, stability and seasonality of production (Townsend, 2001).

Seasonality in production of tropical forages is common, especially in regions with markedly dry seasons, which limits the production of dry matter (Lédo et al., 2008; Souza Sobrinho et al., 2011). For temperate forages, in addition to summer drought, the major limiting factor is the low temperature in winter (Porqueddu et al., 2005). In these cases, the genotype $x$ harvest interaction tends to be significant and can be a complicating factor in genetic material selection, since the best individuals in one harvest may not demonstrate the same performance in another harvest, which reinforces the importance of repeatability study and the determination of minimum number of measures necessary to predict the real value of genotypes for perennial species (Resende, 2002). The selection without interaction information can be practiced 
based on the average genotype behavior along the harvests, with inference by the average genotypic values (Resende et al., 2008). However, environmental interactions may require definitions of strategies that evolve selection for adaptation and stability goals, which requires the determination of suitable genetic resources, type of variety to be released, breeding form, and specific selection processes (Annicchiarico, 2002).

Adequate treatment of data, with identification of harvest and environmental interactions effects, can help to understand the magnitude and occurrence of environmental interference, as well as to define the appropriate strategy to deal with it, since it mainly affects correlations and heterogeneity of variances and covariances among the measures, besides the loss of plots, consequences of the harvests performed in the same experimental unit over time (Annicchiarico, 2002; Piepho and Eckl, 2014).

According to Resende (2007), amid the several alternatives that predict the effects and modeling the correlation structures among the repeated measures in the context of mixed models, besides dealing with the imbalance of data, are: simplified univariate model of repeatability with and without genotype $\mathrm{x}$ harves $\mathrm{t}$ interaction; complete multivariate model of unstructured covariance matrix (UN); autoregressive model with heterogeneous variances (ARH); structured antidependency model (SAD); banded correlation model (Toepitz structure) with correlations for each interval among harvest; compound symmetry structure (CS); compound symmetry structure with heterogeneous variances $(\mathrm{CSH})$.

Univariate models are unrealistic, considering situations that do not in fact occur in field experiments, that is, harvests with genetic correlation equal to 1 over time, phenotypic correlations, or repeatability, with the same magnitude and homogeneous residual genetic variances (Piepho and Eckl, 2014; Resende, 2007). The multivariate model, although complete and optimal, is computationally costly because it considers each harvest as a distinct variable, requiring large amount of computational time and has difficult adjustment when above three harvests analyses are considered (Resende et al., 2008). The CS model is the most used, however, require corrections for high heterogeneities, since homogeneity of variances and covariance among harvests are assumed; the ARH, CSH and SAD models considering also the heterogeneity and the banded model, being more parameterized, should be applied when the correlations of distant measurements are not related to the adjacent measures (Resende, 2007). Thus, Resende et al. (2008) recommend for analysis of repeated measures in perennial forages, in case of high heterogeneity of variance among harvests, the use of ARH, SAD and Toeplitz matrices; however, because the measured variable is the same among harvests, the variances tend to be homogeneous, with the CS matrix being more advantageous, being able to be used in heterogeneous data after the data transformation.

\section{FINAL CONSIDERATIONS}

The use of mixed models in plant breeding has been increasing and demonstrates advantages over ANOVA (Assis et al., 2008; Piepho et al., 2008; Resende, 2002; Resende et al., 2008). One of them, in addition to obtaining more informative results, is the possibility of modeling the variance and covariance structures to overcome the problem of serial correlation and heterogeneity of variances observed in longitudinal data (De Faveri et al., 2015; Piepho and Eckl, 2014). A broad range of available literature explores the forms of model selection and application of this methodology, which, because of the computational facilities available today, make its application viable (Littell et al., 2000; 2006; Liu et al., 2007; Moser, 2004; Resende and Thompson, 2004). The use of pre-established matrices and data transformations may not be the best option, since each set of data, even containing known patterns, can show singular behaviors and tendencies that must be properly analyzed and modeled, especially the environmental interaction effects (Annicchiarico, 2002; De Faveri et al., 2015). In these cases, ignoring or avoiding heterogeneity tends to erroneous or inefficient inferences (Littell et al., 2000).

Another significant aspect is how to detect the variation between measures. Resende (2007) point out the tests of Bartlett, Hartley and Levene, but the first one is very sensitive to the lack of normality of errors and the second one does not present entries for values above twelve treatments, so the Levene's test is replacing the others. According to Huynh and Feldt (1970), the equality of variances for different pairs of treatments is sufficient condition to assume the correlation, or sphericity, among measures, so the Mauchly's test is a multivariate procedure efficiently applied in random variables with normal distribution.

In this aspect, the adequate analysis of data allows the realization of reliable inferences, enabling the advancement in researches and, consequently, efficient results in development and release of cultivars. Annicchiarico et al. (2015) point out the importance of applying the analysis procedures and selection strategies for the genetic variability exploitation of genetic materials 
that can offer many opportunities for forage breeding. In addition, the use of new strategies and technologies, such as the evaluation in densified and in mixed plots and the use of genomic tools, can improve the selection gain in temperate forages, which has shown limited progress in dry matter and seed yields (Annicchiarico et al., 2015; Annicchiarico; Piano, 2010; Grinberg et al., 2016).

Regarding tropical forages, which present genetic improvement considered recent, the use of reliable and adequate statistical tools can help explore the genetic materials variability through the analysis of data and promote the selection of genetic material in a more consistent way, especially considering restricted situations of evaluations and genotype $\mathrm{x}$ harvest interaction in the search for more adapted genotypes (Resende et al., 2006; Simeão et al., 2016; 2017).

The decrease of the area available for animal production, as well as the demand for more efficient and sustainable productive systems, will be decisive in the adoption of mixed forage systems technologies, mainly due to the benefits that mixed pastures confer to the producer, as a reduction in the consumption of inputs and increased productivity (Barcellos et al., 2008; Simeão et al., 2015; Porqueddu et al., 2005).In this context, the low adoption of legumes in tropical pastures tends to be gradually overcome by the release of new, more adapted and productive cultivars, coming from methodologies and strategies increasingly modern and efficiently applied and that seeks new ways of detecting and analyzing genetic variability (Annicchiarico and Piano, 2010; Simeão et al., 2015).

\section{ACKNOWLEDGEMENTS}

The author wishes to thank Capes (Coordenação de Aperfeiçoamento de Pessoal de Nível Superior) for granted doctoral scholarship, FAPAC (Fundação de Amparo à Pesquisa do Estado do Acre) for financial support and Giselle Mariano Lessa de Assis for her doctoral guidance and proposal for this work.

\section{REFERENCES}

[1] Andrade, C. M. S. de, "Características de gramíneas relacionadas com sua compatibilidade com leguminosas em pastos consorciados," in Construção de ideótipos de gramíneas para usos diversos, F. H. D. de Souza, F. de P. Matta and A. P. Fávero, Eds. Brasília, DF: Embrapa, 2013, pp. 37-60.

[2] Andrade, C. M. S. de; Assis, G. M. L. de and Ferreira, A. S. (2015). Eficiência de longo prazo da consorciação entre gramíneas e leguminosas em pastagens tropicais; Proceedings of the 25th Congresso Brasileiro de Zootecnia 2015, ABZ, 2015, Fortaleza, Brazil. Retrieved from https://www.alice.cnptia.embrapa.br/handle/doc/1018549
[3] Annicchiarico, P. (2003). Breeding white clover for increased ability to compete with associated grasses. Journal of Agricultural Science, 140(3): 255-266. https://doi.org/10.1017/S0021859603003198

[4] Annicchiarico, P. (2002). Genotype x environment interactions: challenges and opportunities for plant breeding and cultivar recommendations. In FAO Plant production and protection paper 174. Retrieved from http://www.fao.org/3/y 4391e/y 4391e00.htm

[5] Annicchiarico, P.; Barrett, B.; Brummer, E. C.; Julier, B. and Marshall, A. (2015). Achievements and challenges in improving temperate perennial forage legumes. Critical reviews in Plant Sciences, 34(1-3), 327-380. https://doi.org/10.1080/07352689.2014.898462

[6] Annicchiarico, P.; Pecetti, L.; Abdelguerfi, A.; Bouzgaren, A.; Carroni, A. M.; Hayek, T.; M'Hammadi Bouzina, M. and Mezni, M. (2011). Adaptation of landrace variety germplasm and selection strategies for Lucerne in the Mediterranean basin. Field Crops Reseach, 120(2), 283291. https://doi.org/10.1016/j.fcr.2010.11.003

[7] Annicchiarico, P. and Piano, E. (2000). Response of with clover genotypes to evaluation environments of dense and spaced planting, and implications for selection. Euphytica, 111(2), 111-120. https://doi.org/10.1023/A:1003898913594

[8] Annicchiarico, P. and Proietti, S. (2010). White clover selected for enhanced competitive ability widens the compatibility with grasses and favours the optimization of legume content and forage yield in mown clover-grass mixtures. Grass and Forage Science, 65(3), 318-324. https://doi.org/10.1111/j.1365-2494.2010.00749.x

[9] Araújo, S. A. C.; Deminicis, B. B. and Campos, R. R. S. S. (2008). Melhoramento genético de plantas forrageiras tropicais no Brasil. Archivos de Zootecnia, 57(1), 61-76. Retrieved from http://www.uco.es/organiza/servicios/publica/az/php/img/w eb/25_13_18_1122REVISIONAvaliacaoAraujo.pdf

[10] Assis, G. M. L. de "Melhoramento genético de forrageiras tropicas: importância e complexidade," in Embrapa Acre: ciência e tecnologia para o desenvolvimento sustentável do Sudoeste da Amazônia, Gonçalves, R. C. and Oliveira, L. C., Eds. Rio Branco, AC: Embrapa Acre, 2009. pp. 209220 . Retrieved from http://iquiri.cpafac.embrapa.br/pdf/livro_ufac.pdf

[11] Assis, G. M. L. de.; Beber, P. M.; Miqueloni, D. P. and Simeão, R. M. (2018). Identification of stylo lines with potential to compose mixed pastures with higher productivity. Grass and Forage Science, 73(4), 897-906. https://doi.org/10.1111/gfs.12383

[12] Assis, G. M. L. de; Ruggieri, A. C.; Mercadante, M. E. Z.; Camargo, G. M. F. de and Carneiro Junior, J. M. (2010). Selection of alfafa cultivars adapted for tropical environments with repeated measures using PROC MIXED of SAS System. Plant Genetic Resources, 8(1), 55-62. https://doi.org/10.1017/S1479262109990153

[13] Assis, G. M. L. de and Valentim, J. F. (2009a). Forage peanut breeding program in Brazil; Proceedings of 2nd Simpósio Internacional Sobre Melhoramento de 
Forregairas 2009, Campo Grande, MS, Brazil. Retriev from https://ainfo.cnptia.embrapa.br/digital/bitstream/item/9731 4/1/24896.pdf

[14] Assis, G. M. L. de and Valentim, J. F. (2009b). Programa de melhoramento genético do amendoim forrageiro: avaliação agronômica de acessos no acre. Amazônia: Ciência e Desenvolvimento, 4(8), 207-216. Retrieved from https://www.bancoamazonia.com.br/index.php/component/ edocman/publicacoes/revista-amazonia-cienciadesenvolvimento/revista-amazonia-ciencia-edesenvolvimento-edicao-08? Itemid=

[15] Assis, G. M. L. de; Valentim, J. F.; Carneiro Junior , J. M.; Azevedo, J. M. A. de and Ferreira, A. S. (2008). Seleção de genótipos de amendoim forrageiro para cobertura do solo e produção de biomassa aérea no período de estabelecimento utilizando-se metodologia de modelos mistos. Brazilian Journal of Animal Science, 37(11). 1905-1911. http://dx.doi.org/10.1590/S1516-35982008001100001

[16] Barcellos, A. de O.; Ramos, A. K. B.; Vilela, L. and Martha Junior, G. B. (2008). Sustentabilidade da produção animal baseada em pastagens consorciadas e no emprego de leguminosas exclusivas, na forma de banco de proteína, nos trópicos brasileiros. Brazilian Journal of Animal Science, 37(spe). 51-67. http://dx.doi.org/10.1590/S151635982008001300008

[17] Basso, K. C.; Resende, R. M. S.; Valle, C. B. do; Gonçalves, M. C. and Lempp, B. (2009). Avaliação de acessos de Brachiaria brizantha Stapf e estimativas de parâmetros genéticos para caracteres agronômicos. Acta Scientiarum. Agronomy, 31(1). 17-22. http://dx.doi.org/10.4025/actasciagron.v31i1.6605

[18] Batello, C.; brinkman, R.; Mannetje, L.; Martinez, A. and Suttie, J. (2008). Plant genetic resources of forage crops, pasture and rangelands. In Thematic background. Retrieved from

http://www.fao.org/fileadmin/templates/agphome/documen ts/PGR/SoW2/thematicstudy_forage.pdf

[19] Boelt, B.; Julier, B.; Karagic, Đ. and Hampton, J. (2015). Legume seed production meeting market requirements and economic impacts. Critical Reviews in Plant Sciences, 34(1-3). 412-427. https://doi.org/10.1080/07352689.2014.898477

[20] Cilas, C.; Montagnon, C. and Bar-Hen, A. (2011). Yield stability in clones of Coffea canephora in the short and medium term: longitudinal data analyses and measures of stability over time. Tree Genetics and Genomes, 7(2). 421429. https://doi.org/10.1007/s11295-010-0344-4

[21] Coelho, A. M. and Barbin, D. (2006). Simulação de dados visando à estimação de componentes de variância e coeficientes de herdabilidade. Revista de Matemática $e$ Estatística, 24(2). 103-120. Retrieved from http://jaguar.fcav.unesp.br/RME/fasciculos/v24/v24_n2/A7 _Angela_Decio.pdf

[22] De Faveri, J.; Verbyla, A.; Pitchford, W. S.; Venkatanagappa, S. and Cullis, B. R. (2015). Statistical methods for analysis of multi-harvest data from perennial pasture variety selection trials. Crop and Pasture Science, 66(9). 947-962. https://doi.org/10.1071/CP14312

[23] Diehl, M. S.; Olivo, C. J.; Agnolin, C. A.; Bratz, V. F.; Bem, C. M.; Aguirre, P. F.; Glienk, C. L.; Correa, M. R. and Serafim, G. (2013). Produtividade de sistemas forrageiros consorciados com leguminosas. Arquivo Brasileiro de Medicina Veterinária e Zootecnia, 65(5). 1527-1536. http://dx.doi.org/10.1590/S010209352013000500034

[24] Embrapa - Empresa Brasileira de Pesquisa Agropecuária. Balanço Social 2013. Retrieved from https://bs.sede.embrapa.br/2013/balsoc13.html

[25] Falco, J. da S.; Fernandes, C. D.; Verzignassi, J. R.; Mallmann, G.; Queiróz, C. de A.; Chagas, H. A.; Batista, M. V. and Quetez, F. A. (2016). Reação de genótipos de Stylosanthes capitata à antracnose. Summa Phytopathologica, 42(2). 140-148. http://dx.doi.org/10.1590/0100-5405/2055

[26] Ferreira, A. S.; Pedreira, C. G. and Marassato, C. M. (2013). Sward structural characteristics of perennial peanut genotypes as affected by harvest frequency. Tropical Grasslands, $1(1) . \quad 74-75$. https://doi.org/10.17138/tgft(1)74-75

[27] Figueiredo, U. J. de; Nunes, J. A. R. and Valle, C. B. do. (2012). Estimation of genetic parameters and selection of Brachiaria humidicola progenies using a selection index. Crop Breeding and Applied Biotechnology, 12(4). 237244. http://dx.doi.org/10.1590/S1984-70332012000400002

[28] Freitas, A. R.; Ferreira, R. P. and Moreira, A. (2011). Análise de dados de medidas repetidas por meio do modelo linear geral e do modelo misto. Revista de Ciências Agrárias, 54(3). 214-224. Retrieved from https://periodicos.ufra.edu.br/index.php/ajaes/article/view/3 07

[29] Freitas, E. G.; Barbin, D.; Barbosa, G. V. S.; Carneiro, M. S. and Bassinello, A. I. (2008). Modelo univariado aplicado a dados longitudinais de cana-de-açúcar. Revista Brasileira de Biometria, 26(2). 93-106. Retrieved from http://jaguar.fcav.unesp.br/RME/fasciculos/v26/v26_n2/A6 _Edjane.pdf

[30] Garcia, M.; Vigna, B. B. Z; Sousa, A. C. B.; Jungmann, L.; Cidade, F. W.; Toledo-Silva, G.; Francisco, P. M.; Chiari, L.; Carvalho, M. A.; Karia, C. T.; Faleiro, F. G.; Godoy, R.; Dalliagnoll, M.; Pagliarini, S. S.; Souza, F. H. D.; Souza-Chies, T. T.; Jank, L.; Resende, R. M. S.; Valle, C. B.; Zucchi, M. I. and Souza, A. P. (2013). Molecular genetic variability, population structure and mating system in tropical forages. Tropical Grasslands, 1(1). 25-30. https://doi.org/10.17138/tgft(1)25-30

[31] Grahan, P. H. and Vance, C. P. (2003). Legumes: Importance and constraints to greater use. Plant Physiology, 131(3). 872-877. https://doi.org/10.1104/pp.017004

[32] Grinberg, N. F.; Lovatt, A.; Hergarty, M.; Lovatt, A.; Skøt, K. P.; Kelly, R.; Blackmore, T.; Thorogood, D.; King, R.; Armstead, I.; Poewll, W. and Skøt, L. (2016). Implementation of genomic prediction in Lolium perenne 
(L.) breeding populations. Frontiers in Plant Science, 7(133). https://doi.org/10.3389/fpls.2016.00133

[33] Hayes, B. J.; Cogan, N. O. I.; Pembleton, L. W.; Goddard, M. E.; Wang, J.; Spangenberg, G. C. and Forster, J. W. (2013). Prospects for genomic selection in forage plant species. Plant Breeding, 132(2). 133-143. https://doi.org/10.1111/pbr.12037

[34] Henderson, C. R. (1973). Sire evaluation and genetic trends; Proceedings of the Animal Breeding and Genetics Symposium in Honor of J. Lush, American Society of Animal Science 1973, Champaign, pp. 10-41. https://doi.org/10.1093/ansci/1973.Symposium.10

[35] Huynh, H. and Feldt, L. S. (1970). Conditions under which mean square rations in repeated measurements designs have exact F-distributions. Journal of the American Statistical Association, 65(332). 1582-1589. https://doi.org/10.2307/2284340

[36] Jank, L.; Barrios, S. C.; Valle, C. B. do; Simeão, R. M. and Alves, G. F. (2014). The value of improved pastures to Brazilian beef production. Crop and Pasture Science, 65(11). 1132-1137. https://doi.org/10.1071/CP13319

[37] Jank, L.; Valle, C. B. and Resende, R. M. S. (2011). Breeding tropical forages. Crop Breeding and Applied Biotechnology, 11(spe). 27-34. http://dx.doi.org/10.1590/S1984-70332011000500005

[38] Lédo, F. J. da S.; Pereira, A. V.; Souza Sobrinho, F. de; Auad, A. M.; Jank, L. and Oliveira, J. S. e. (2008). Estimativas de repetibilidade para caracteres forrageiros em Panicum maximum. Ciência e Agrotecnologia, 32(4). 1299-1303. 70542008000400040

[39] Littell, R. C.; Pendergast, J. and Natatajan, R. (2000). Modelling covariance structure in the analysis of repeated measures data. Statistics in Medicine, 19(13). 1993-1819. https://doi.org/10.1002/10970258(20000715)19:13<1793::AID-SIM482>3.0.CO;2-Q

[40] Littell, R.; Milliken, G. A.; Stroup, W. W.; Wolfinger, R. D. and Schabenberger, O. SAS for mixed models. 2th ed., Cary, US: SAS Institute Inc., 2006. Retrieved from http://s1.nonlinear.ir/epublish/book/SAS_for_Mixed_Mode 1s_1590475003.pdf

[41] Liu, C.; Cao, D.; Chen, P. and Zagar, T. (2007). Random and Repeated statements: how to use them to model the covariance structure in Proc Mixed; Proceedings of the Midwest SAS Users Group Conference 2007, MidWest SAS Users Group. Des Moines. Retrieved from http://www.mwsug.org/pastconf

[42] Locascio, J. J. and Atri, A. (2011). An Overview of Longitudinal Data Analysis Methods for Neurological Research. Dementia and Geriatric Cognitive Disorders Extra, 1(1). 330-357. https://doi.org/10.1159/000330228

[43] Martuscello, J. A; Braz, T. G. dos S.; Jank, L.; Cunha, D. de N. F. V. da; Lima, B. P. da S. and Oliveira, L. P. de. (2015). Repeatability and phenotypic stabilization of Panicum maximum accessions. Acta Scientiarum. Animal Sciences, 37(1).

15-21. http://dx.doi.org/10.4025/actascianimsci.v37i1.23206
[44] Miranda, E. M. de; Silva, E. M. R. da and Sagin Junior, O. J. (2010). Comunidades de fungos micorrízicos arbusculares associados ao amendoim forrageiro em pastagens consorciadas no Estado do Acre, Brasil. Acta Amazonica, 40(1). 13-22. http://dx.doi.org/10.1590/S004459672010000100002

[45] Montardo, D. P.; Dall'Agnol, M.; Crusius, A. F. and Paim, N. R. (2003). Análise de trilha para rendimento de sementes em trevo vermelho (Trifolium pratense L.). Brazilian Journal of Animal Science, 32(5). 1076-1082. http://dx.doi.org/10.1590/S1516-35982003000500007

[46] Moser, E. B. (2004). Repeated Measures Modeling With PROC MIXED. Proceedings of the 29th Annual SAS® Users Group International Conference, SAS Institute Inc, 2004, Montreal. Retrieved from https://support.sas.com/resources/papers/proceedings/proce edings/sugi29/188-29.pdf

[47] Oliveira, J. A.; López, J. H. and Palencia, P. (2013). Agromorphological characterization, cyanogenesis and productivity of accessions of White clover (Trifolium repens L.) collected in Northern Spain. Czech Journal of Genetic and Plant Breeding, 49(1). 24-35. https://doi.org/10.17221/157/2011-CJGPB

[48] Olivo, C. J.; Nörnberg, J. L.; Meinerz, G. R.; Agnolin, C. A.; Machado, P. R.; Marx, F. R.; Diehl, M. S.; Foletto, V.; Aguirre, P. F.; Araújo, T. L. da R.; De Bem, C. M. and Santos, J. C. dos. (2012). Produtividade e valor nutritivo de pastos consorciados com diferentes espécies de leguminosas. Ciência Rural, 42(11). 2051-2058. http://dx.doi.org/10.1590/S0103-84782012005000098

[49] Olivo, C. J.; Steinwandter, E.; Agnolin, C. A.; Meinerz, G. R.; Santos, J. C. dos; De Bem, C. M.; Aguirre, P. F.; Machadi, P. R. and Araújo, T. L. da R. (2010). Contribuição dos componentes e composição química de pastagens em sistemas forrageiros constituídos por diferentes leguminosas. Ciência Rural, 40(12). 2534-2540. http://dx.doi.org/10.1590/S0103-84782010001200016

[50] Onofri, A.; Carbonell, E. A.; Piepho, H. P.; Mortimer, A. M. and Cousend, R. D. (2010). Current statistical issues in Weed Research. Weed Research, 50(1). 5-24. https://doi.org/10.1111/j.1365-3180.2009.00758.x

[51] Patterson, H. D. and Thompson, R. (1971). Recovery of inter-block information when block sizes are unequal. Biometrika, 58(3). 545-554. http://dx.doi.org/10.2307/2334389

[52] Pereira, A. V.; Souza Sobrinho, F. de; Souza, F. H. D. de and Lécio, F. J. da S. (2003). Tendências no melhoramento genético e produção de sementes de forrageiras no Brasil, Proceedings of the 7th Simpósio de Atualização em Genética e Melhoramento de Plantas, UFLA, 2003, Lavras, Brazil. Retrieved from https://www.alice.cnptia.embrapa.br/handle/doc/46610

[53] Pereira, A. V.; Valle, C. B. do; Ferreira, R. de P. and Miles, J. H, "Melhoramento de forrageiras tropicais," in Recursos genéticos e melhoramento: plantas, Nass, L. L.; Valois, A. C. C.; Melo, I. S. de and Valadares-Inglis, M. C, Eds. Rondonópolis: Fundação MT, 2001. pp. 549-602. 
[54] Peres Netto, D.; Rodrigues, A. de A.; Wechsler, F. S.; Ferreira, R. P.; Mendonça, F. C. and Freitas, A. R. (2011). Desempenho de vacas leiteiras em pastagem de alfafa suplementada com silagem de milho e concentrado e viabilidade econômica do sistema. Arquivo Brasileiro de Medicina Veterinária e Zootecnia, 63(2). 399-407. http://dx.doi.org/10.1590/S0102-09352011000200018

[55] Piepho, H. P. and Eckl, T. (2014). Analysis of series of variety trials with perennial crops. Grass and Forage Science, 69(3). 431-440. https://doi.org/10.1111/gfs.12054

[56] Piepho, H. P. and Möhring, J. (2006). Selection in cultivar trials: is it ignorable? Crop Science,46(1). 192-201. https://doi.org/10.2135/cropsci2005.04-0038

[57] Piepho, H. P.; Möhring, J.; Melchinger, A. E. and Büchse, A. (2008). BLUP for phenotipyc selection in plant breeding and variety testing. Euphytica, 161(3). 209-228. https://doi.org/10.1007/s 10681-007-9449-8

[58] Porqueddu, C.; Maltoni, S. and Mclvor, J. G "Strategies to mitigate seasonality of production in grassland-based systems." in Grassland: A Global Resource, Mcgilloway, D. A. Ed. Wageningen: Wageningen Academic Publishers, 2005, pp. 111-122.

[59] Rao, I.; Peters, M.; Castro, A.; Schultze-Kraft, R.; White, D.; Fisher, M.; Miles, J.; Lascano, C.; Blümmel, M.; Bungenstab, D.; J. Tapasco; Hymam, G.; Bolliger, A.; Paul, B.; Van Der Hoek, R.; Maass, B.; Tiemann, T.; Cuchillo, M.; Douxchamps, S.; Villanueva, C.; Rincón, Á.; Ayarza, M.; Rosentock, T.; Subbarao, G.; Arango, J.; Cardoso, J.; Worthington, M.; Chirinda, N.; Notenbaert, A.; Jenet, A.; Schimidt, A.; Vivas, N.; Lefroy, R.; Fahrney, K.; Guimarães, E.; Tohme, J.; Cppk, S.; Herrero, M.; Chacón, M.; Ssearchinger, T. and Rudel, T. (2015). LivestockPlus - The sustainable intensification of foragebased agricultural systems to improve livelihoods and ecosystem services in the tropics. Tropical Grasslands, 3(2). 59-82. https://doi.org/10.17138/TGFT(3)59-82

[60] Resende, M. D. V. de. Genética biométrica e estatística no melhoramento de plantas perenes. Brasília, DF: Embrapa Informação Tecnológica, 2002.

[61] Resende, M. D. V. de. Matemática e estatística na análise de experimentos e no melhoramento genético. Colombo: Embrapa Florestas, 2007.

[62] Resende, M. D. V. de and Duarte, J. B. (2007). Precisão e controle de qualidade em experimentos de avaliação de cultivares. Pesquisa Agropecuária Tropical, 37(3). 182$194 . \quad$ Retrieved from https://www.revistas.ufg.br/pat/article/view/1867

[63] Resende, M. D. V. de and Thompson, R. (2004). Factor analytic multiplicative mixed models in the analysis of multiple experiments. Revista de Matemática e Estatística, 24(2). 31-52. Retrieved from http://jaguar.fcav.unesp.br/RME/fasciculos/v22/v22_n2/A3 _MDeon.pdf

[64] Resende, M. D. V. de; Thompson, R. and Welham, S. (2006a). Multivariate spatial statistical analysis of longitudinal data in perennial crops. Revista de Matemática e Estatística, 24(1). 147-169. https://pdfs.semanticscholar.org/7dd8/6f2e8464e65b5b1f8f 28b9eea71dfcfdc6fc.pdf

[65] Resende, R. M. S.; Casler, M. D. and Resende, M. D. V. de. (2014). Genomic selection in forage breeding: accuracy and methods. Crop Science, 54(1). 1-14. http://dx.doi.org/10.2135/cropsci2013.05.0353

[66] Resende, R. M. S.; Jank, L.; Valle, C. B. do and Bonato, A. L. V. (2004). Biometrical analysis and selection of tetraploid progenies of Panicum maximum using mixed model methods. Pesquisa Agropecuária Brasileira, 39(4). 335-341. 204X2004000400006

[67] Resende, R. M. S.; Resende, M. D. V. de; Laura, V. A.; Jank, L. and Valle, C. B. do. (2006b). Genotypic evaluations of accessions and individual selection in Stylosanthes spp. by simulated BLUP method. Crop Breeding and Applied Biotechnology, 6(4). 253-260. Retrieved from http://cbab.sbmp.org.br/arquivos/1846

[68] Resende, R. M. S.; Valle, C. B. do and Jank. L. Melhoramento de forrageiras tropicais. Campo Grande: Embrapa Gado de Corte, 2008.

[69] Rubiales, D.; Fondevilla, S.; Chen, W.; Gentzbittel, L.; Higgins, T. J. V.; Castillejo, M. A.; Singh, K. B. and Rispail, N. (2015). Achievements and challenges in legume breeding for pest and disease resistance. Critical reviews in Plant Sciences, 34(1-3). 195-236. https://doi.org/10.1080/07352689.2014.898445

[70] Schneider, R.; Dall'Agnol, M.; Montardo, D. P.; Pereira, E. A.; Martins, J. J.; Saraiva, K. M. and Tafernaberri Junior, V. (2011). Avaliação agronômica de progênies de policruzamento de trevo-branco em dois locais do Rio Grande do Sul. Brazilian Journal of Animal Science, 40(9). 1879-1885. http://dx.doi.org/10.1590/S151635982011000900006

[71] Shelton, H. M.; Franzel, S. and Peters, M. (2005). Adoption of tropical legume technology around the world: analysis of success. Tropical Grasslands, 39(4). 198-209. Retrieved from http://www.tropicalgrasslands.asn.au/Tropical\%20Grasslan ds\%20Journal\%20archive/PDFs/Vol_39_2005/Vol_39_04 _2005_pp 198_209.pdf

[72] Silva, A. L. C.; Santos, M. V. F. dos; Dubeux Júnior, J. C. B.; Lira, M. de A.; Ferreira, R. L. C.; Freitas, R. V. de; Cunha, M. V. da and Silva, M. da C. (2010). Variabilidade e herdabilidade de caracteres morfológicos em clones de capim-elefante na Zona da Mata de Pernambuco. Brazilian Journal of Animal Science, 39(10). 2132-2140. http://dx.doi.org/10.1590/S1516-35982010001000005

[73] Simeão, R. M.; Assis, G. M. L.; Montagner, D. B. and Ferreira, R. C. U. (2017). Forage peanut (Arachis spp.) genetic evaluation and selection. Grass and Forage Science, 72(2). 322-332. https://doi.org/10.1111/gfs.12242

[74] Simeão, R. M.; Jank, L.; Valle, C. B. do; Barrios, S. C. L. and Santos, M. F. (2015). Melhoramento de forrageiras tropicais Proceedings of the 2nd Simpósio de Pastagem e Forragicultura do Campo das Vertentes, UFSJ, 2015, São 
João del Rei, Brazil. Retrieved from https://www.alice.cnptia.embrapa.br/handle/doc/1012586

[75] Simeão, R. M.; Silva, A.; Valle, C.; Resende, M. D. and Medeiros, S. (2016). Genetic evaluation and selection index in tetraploid Brachiaria ruziziensis. Plant Breeding, 135(2). 246-253. https://doi.org/10.1111/pbr.12353

[76] Smith, A. B.; Cullis, B. R. and Thompson, R. (2005). The analysis of crop cultivar breeding and evaluation trials: an overview of current mixed model approaches. Journal of Agricultural Science, 143(6). 449-462. https://doi.org/10.1017/S0021859605005587

[77] Souza Sobrinho, F.; Lédo, F. J. da S. and Kopp, M. M. (2011). Estacionalidade e estabilidade de produção de forragem de progênies de Brachiaria ruziziensis. Ciência e Agrotecnologia, 35(4). 685-691. http://dx.doi.org/10.1590/S1413-70542011000400006

[78] Townsend, C. R. Avaliação agronômica de forrageiras. Porto Velho: Embrapa Rondônia, 2011. 24 p. (Documentos, 147).

[79] Valentim, J. F.; Andrade, C. M. S. de; Mendonça, H. A. de and Sales, M. F. L. (2003). Velocidade de estabelecimento de acessos de amendoim forrageiro na Amazônia Ocidental. Brazilian Journal of Animal Science, 32(6). 1569 - $\quad 1577 . \quad$ http://dx.doi.org/10.1590/S151635982003000700005

[80] Valle, C. B. do; Jank, L. and Resende, R. M. S. (2009). O melhoramento de forrageiras tropicais no Brasil. Ceres, 56(4). 460-472. Retrieved from http://www.ceres.ufv.br/ojs/index.php/ceres/article/view/34 $54 / 1352$

[81] Volaire, F.; Barkaoui, K. and Norton, M. (2014). Designing resilient and sustainable grassland for a drier future: adaptive strategies, functional traits and biotic interactions. European Journal of Agronomy, 52(B). 81-89. https://doi.org/10.1016/j.eja.2013.10.002

[82] Wang, C.; Andersson, B. and Waldmann, P. (2009). Genetic analysis of longitudinal height data using random regression. Canadian Journal of Forest Research, 39(10). 1939-1948. https://doi.org/10.1139/X09-111

[83] Zamudio, F.; Wolfinger, R.; Stanton, B. and Guerra, F. (2008). The use of linear mixed model theory for the genetic analysis of repeated measures from clonal tests of forest trees. I. A focus on spatially repeated data. Tree Genetics and Genomes, 4(2). 299-313. https://doi.org/10.1007/s11295-007-0110-4 